\title{
Synthesis of $\mathrm{C}_{60}(\mathrm{OH})_{18-20}$ in Aqueous Alkaline Solution Under $\mathrm{O}_{2}$-Atmosphere
}

\section{Gustavo Catão Alves, ${ }^{*}, a$ Luiz Orlando Ladeira, ${ }^{a}$ Ariete Righi, ${ }^{a}$ Klaus Krambrock, ${ }^{a}$ Hállen Daniel Calado, ${ }^{b}$ Rossimiriam Pereira de Freitas Gil $^{b}$ and Maurício Veloso B. Pinheiro ${ }^{a}$}

\author{
${ }^{a}$ Departamento de Física and ${ }^{b}$ Departamento de Química, ICEx, Universidade Federal de Minas Gerais, \\ Av. Antônio Carlos 6627, 31270-901 Belo Horizonte-MG, Brazil
}

\begin{abstract}
Neste trabalho apresentamos uma variação da síntese de derivados hidro-solúveis de fullerenos, também conhecidos como fullerols, visando aplicações biomédicas. Esta síntese foi baseada em um processo que utiliza poli-etileno glicol (PEG400) como catalisador de transferência de fase entre uma solução de fullerenos em benzeno e outra solução aquosa de $\mathrm{NaOH}$. A polihidroxilação dos fullerenos ocorreu na solução de $\mathrm{NaOH}$ sob um fluxo contínuo de $\mathrm{O}_{2}$ visando aumentar o ganho da reação. Os produtos foram caracterizados com espectroscopia na região do infravermelho, ressonância magnética nuclear do ${ }^{13} \mathrm{C}$, análise termogravimétrica e absorção óptica. A formação de fullerols $\mathrm{C}_{60}(\mathrm{OH})_{18-20}$, com alta eficiência, foi demonstrada.
\end{abstract}

In this work we report on an alternative synthesis of water-soluble fullerenes known as fullerols, aiming for biomedical applications. The synthesis is based on a process in which polyethylene glycol (PEG400) is used as phase-transfer catalyst between fullerene/benzene and aqueous $\mathrm{NaOH}$ solutions. The polyhydroxylation of the fullerenes occurs in the $\mathrm{NaOH}$ solution under a continuous flow of $\mathrm{O}_{2}$ to enhance the reaction yield. The resulting compound was characterized with infrared spectroscopy, nuclear magnetic resonance, thermo-gravimetric analysis and optical absorption. The formation of $\mathrm{C}_{60}(\mathrm{OH})_{18-20}$ in high yields was confirmed.

Keywords: fullerene, fullerol, polyhydroxylation, FTIR, NMR, TG

\section{Introduction}

Fullerenes are a large family of super-aromatic threedimensional molecules. They contain dozens of $\mathrm{sp}^{2}$ hybridized carbon atoms arranged in hexagons and pentagons. The latter are responsible for distributing the strain caused by the unique molecular shape of the carbon cage. The most prominent fullerene is the Buckyball $\mathrm{C}_{60}$, a truncated icosahedron of $I_{h}$ symmetry discovered twenty years ago. ${ }^{1}$ Due to their electronic structure the fullerene can be decorated exohedrally with a large number of different functional groups. On the other hand, because of its spherical shape with nanometric diameter, several atoms and smaller molecules can be virtually trapped in its cage. The combination of these two unusual properties makes the fullerenes a very attractive family of molecules for a vast range of biomedical applications: drug carriers; the inhibition of enzymes of the HIV virus; contrasts for MRI and X-ray computer tomography; radio-immunotherapy; as well as drugs against neurodegenerative

*e-mail: gustavo.catao@terra.com.br disorders such as Parkinson's, Alzheimer's and Lou Gehrig's, in which the fullerenes can act as free-radical scavengers (For a complete review on the field see Bosi et al.). ${ }^{2}$

One of the key drawbacks for the applications of fullerenes in biomedicine is their low solubility in water. In order to make them water-soluble, one needs to functionalize them with polar groups like- $\mathrm{OH}$ and -COOH. From all watersoluble fullerenes, the ones with several -OH groups attached, usually known as fullerols or fullerenols, are by far the most intensively investigated. They are excellent free-radical scavengers, and have their anti-oxidant properties already tested in cortical neurons. ${ }^{3-6}$

There are several ways to synthesize the fullerols. However, most of these methods are based on the complex hydrolysis of fullerene derivatives. ${ }^{7-13}$ The most simple method by far, is based on the phase-transfer of $\mathrm{C}_{60}$ in benzene or toluene to an aqueous solution of $\mathrm{NaOH}$, where the polyhydroxylation takes place. This phase-transfer is usually accomplished with tetrabutyl-amonium hydroxide (TBAH) as the phase-transfer catalyst. ${ }^{14-16}$ Recently, this method has been revised in the literature. ${ }^{17}$ By means of 
electron paramagnetic resonance (EPR) and magnetic susceptibility measurements, the fullerol so produced was shown to be a complex paramagnetic salt of chemical formula $\mathrm{Na}_{2-3}^{+}\left[\mathrm{C}_{60} \mathrm{O}_{7-9}(\mathrm{OH})_{12-15}\right]^{(2-3)-}$, rather than simply polyhydroxylated fullerenes. Almost at the same time, a new synthesis was reported in which the TBAH catalyst was substituted by polyethilene-glycol (PEG). ${ }^{18}$ In this work the authors claimed that a simple fullerol with an average number of $\mathrm{OH}$ groups of 27 was produced with a yield of $80.4 \%$. The characterization of water-soluble products was based on mass spectroscopy analysis, Fourier-transform infrared spectroscopy (FTIR) and nuclear magnetic resonance (NMR). With a $300 \mathrm{MHz}$ NMR and using $\left(\mathrm{CD}_{3}\right)_{2} \mathrm{SO}$ as a solvent, a signal with a chemical shift of 3.35 ppm was observed. This shift was attributed to the hydroxyl protons of the fullerol. However, this conclusion must be questioned since water impurities in the $\left(\mathrm{CD}_{3}\right)_{2} \mathrm{SO}$ may result in a signal line with a similar chemical shift. ${ }^{19}$

In this paper, we present a modification of the method by Zhang et $a l .{ }^{18}$ for a large scale production of fullerols, from sublimated $\mathrm{C}_{60}$, in $\mathrm{O}_{2}$-rich environment. We obtained fullerols with an average number of $\mathrm{OH}$ of $\sim 18$ to 20 and with a yield of $87 \%$. The products were characterized with FTIR, ${ }^{13} \mathrm{C}$ NMR, optical absorption and thermogravimetric analysis (TGA).

\section{Experimental}

\section{Materials and methods}

The synthesis of fullerenes was performed in an arc discharge chamber adapted from a Czochralski crystal growing furnace from Arthur D. Little, Inc. Modifications followed standard carbon nanotube and fullerene growth conditions widely described in the literature. ${ }^{20}$ High purity graphite electrodes were purchased from Carbone Lorraine Co., with $10 \mathrm{~mm}$ in diameter and $100 \mathrm{~mm}$ in length. Sublimation of extracted soot took place in a homemade tubular quartz furnace under high-vacuum $\left(\sim 10^{-4} \mathrm{~Pa}\right)$. For polyhydroxylation of purified fullerenes, we utilized 99.8\% pure methanol from Vetec Química Fina Ltda, 97.0\% pure sodium hydroxide and $99.0 \%$ pure benzene from Labsynth Ltda. Polyethilene glycol (PEG-400) was purchased from Aldrich Chemical Company Inc. The filtrations were done with P42 paper filters from JProlab Ltda. Infrared spectra for sublimated fullerenes were acquired in a standard Fourier Transform Infrared Spectrometer (FTIR). The TGA measurements were done with a TA-Instruments 2100 Thermal Analysis equipment with a $50 \mathrm{~mL} \mathrm{~min}{ }^{-1}$ nitrogen flow. The optical absorption spectra were recorded with a Jenway spectrometer. The ${ }^{13} \mathrm{C}$ NMR spectrum of the fullerol was measured in a 400 $\mathrm{MHz}$ NMR spectrometer operated at frequency of $100 \mathrm{MHz}$ with $\mathrm{D}_{2} \mathrm{O}$ as solvent.

\section{Synthesis of fullerenes}

Fullerenes were produced by arc discharge, as usually described in the literature. ${ }^{20}$ Synthesis conditions were $\mathrm{He}$ pressure between $13-20 \mathrm{~Pa}$, with a $15-20 \mathrm{~V}, 100 \mathrm{~A}$ current. These conditions are often cited in the literature as ideal for high fullerene yield, and generate around $1 \mathrm{~g}$ of carbon soot. Purification of the collected soot was carried out via sublimation of the fullerenes, where an initial mass of $2.5 \mathrm{~g}$ of soot is gradually heated to $650^{\circ} \mathrm{C}$ at $10^{-4} \mathrm{~Pa}$. This temperature is kept for 48 hours, causing the sublimated fullerenes to deposit on the quartz walls of the tube. A second quartz tube is inserted in the system to provide a deposition area that is easier to remove for fullerene extraction. The above described sublimation process generates about $120 \mathrm{mg}$ ( 5\% yield) of a high purity $\mathrm{C}_{60} / \mathrm{C}_{70}$ mixture, as confirmed by IR spectroscopy (see Figure 1). Purification was carried out via Soxhlet extraction, but the obtained materials showed contamination from the solvents used in the process. Thus for the fullerol synthesis we used sublimated fullerenes.

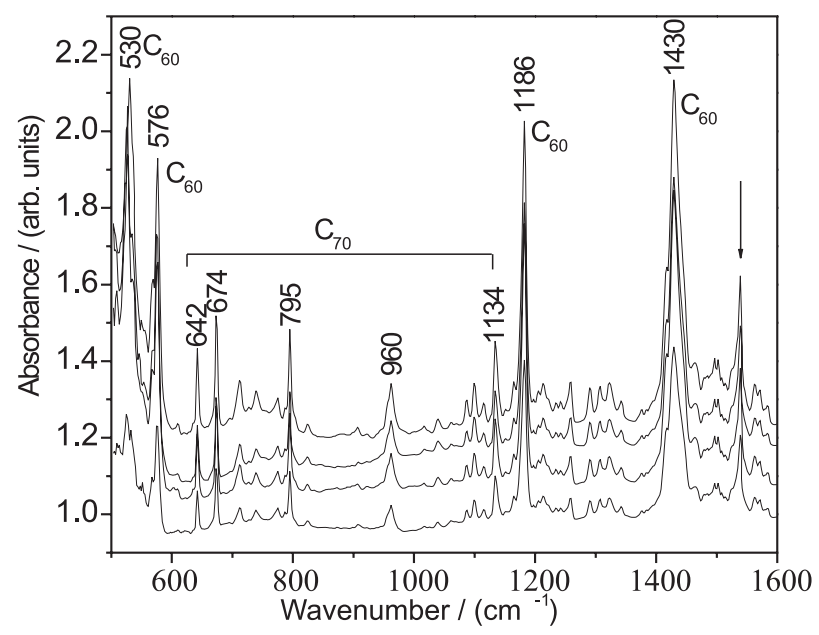

Figure 1. FTIR spectra of four different sublimated fullerene samples, containing $\mathrm{C}_{60}$ and $\mathrm{C}_{70}$. The peak labeling for $\mathrm{C}_{60}$ and $\mathrm{C}_{70}$ were done after reference 20 . The four $\mathrm{C}_{60}$ lines are due to the $\mathrm{F}_{1 \mathrm{u}}$ modes. The arrow indicates an intermolecular vibration. The lines in-between are due to second order active modes.

\section{Polyhydroxylation of fullerenes}

After obtaining and characterizing the purified fullerenes, the production of fullerols was performed using a slight modification of the process detailed by 
Zhang et al. ${ }^{18}$ The process consists of slowly adding 5 $\mathrm{mL}$ of a $\mathrm{NaOH}$ solution $\left(25 \mathrm{~mol} \mathrm{~L}^{-1}\right)$ to $\mathrm{a}_{60} / \mathrm{C}_{70}$ benzene solution $(125 \mathrm{mg}$ in $175 \mathrm{~mL}$ ) followed by the phase transfer of the fullerenes to the aqueous solution by adding drop-wise $5 \mathrm{~mL}$ of the diluted catalyst PEG 400 in water (1:1 vol). The mixture was magnetically stirred for $6 \mathrm{~h}$ with a constant oxygen flux bubbled through the solution. Although the precipitation of the solution occurred in less than an hour, reaction times were extended to ensure that a high percentage of fullerenes reacted with the aqueous $\mathrm{NaOH}$. A brown sludge precipitated from the mixture forming two phases, a water soluble brown sludge and a transparent benzene solution. The resulting mixture was further stirred and gently heated for $48 \mathrm{~h}$ in order to remove all benzene. After that, $40 \mathrm{~mL}$ of de-ionized $\mathrm{H}_{2} \mathrm{O}$ was added and the magnetic stirring continued for 1 hour in the presence of $\mathrm{O}_{2}$. The mixture was then dried in air to remove any residual benzene and diluted in $80 \mathrm{~mL}$ of de-ionized $\mathrm{H}_{2} \mathrm{O}$. Due to excess of $\mathrm{NaOH}$ the $\mathrm{pH}$ was 14 . After filtering, a water-insoluble fullerene/fullerol mixture was retained in the filters. Once filtered, the solution was reduced to $10 \mathrm{~mL}$, and $690 \mathrm{~mL}$ of methanol was added. This mixture was stirred for 5 minutes and another filtration procedure took place. The material retained in the filters was diluted in $100 \mathrm{~mL}$ of water. The process of methanol addition, filtration and dilution in water was repeated several times until $\mathrm{pH} 7$ was reached. At this point the solution was concentrated, filtered through an ordinary paper filter and dried. This process resulted in $161 \mathrm{mg}$ of watersoluble fullerol, a yield of $87 \%$ with respect to the amount of fullerenes initially used.

\section{Results and Discussion}

Figure 2 shows the IR spectrum of a fullerol synthesis. The spectrum is dominated by a broad band at $3380 \mathrm{~cm}^{-1}$ due to the stretching mode of the $\mathrm{OH}$ groups, as well as other peaks at $1600 \mathrm{~cm}^{-1}(\mathrm{C}=\mathrm{C}), 1390 \mathrm{~cm}^{-1}(\mathrm{C}-\mathrm{OH})$ and $1055 \mathrm{~cm}^{-1}$ (C-O). All these bands have been reported before for the compound as belonging to the fullerol molecules. ${ }^{21-25}$

Figure 3 shows the ${ }^{13} \mathrm{C}$ NMR spectrum measured at $400 \mathrm{MHz}$ operating at $100 \mathrm{MHz}$ and room temperature with $\mathrm{D}_{2} \mathrm{O}$ as a solvent. The signal to the left (at $\delta=166$ ppm) has a typical chemical shift of carbons with $\mathrm{sp}^{2}$ hybridization in alkenes and probably belongs to the carbons without $\mathrm{OH}$ of the distorted cage of the fullerol. ${ }^{19}$ For comparison, in the undistorted $\mathrm{C}_{60}$ cage with $I_{h}$ symmetry, the ${ }^{13} \mathrm{C}$ NMR spectrum has a single signal at $\delta=143 \mathrm{ppm}$, both for liquids and for solids

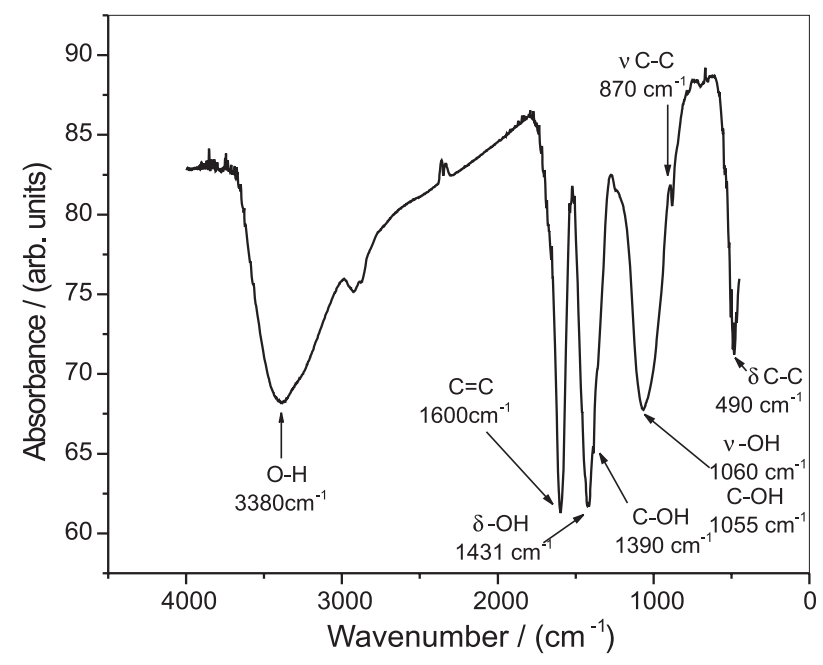

Figure 2. Fourier-Transformed Infrared (FTIR) absorption spectrum of a fullerol sample. Peaks marked $v$ and $\delta$ refer to stretching and bending modes, respectively.

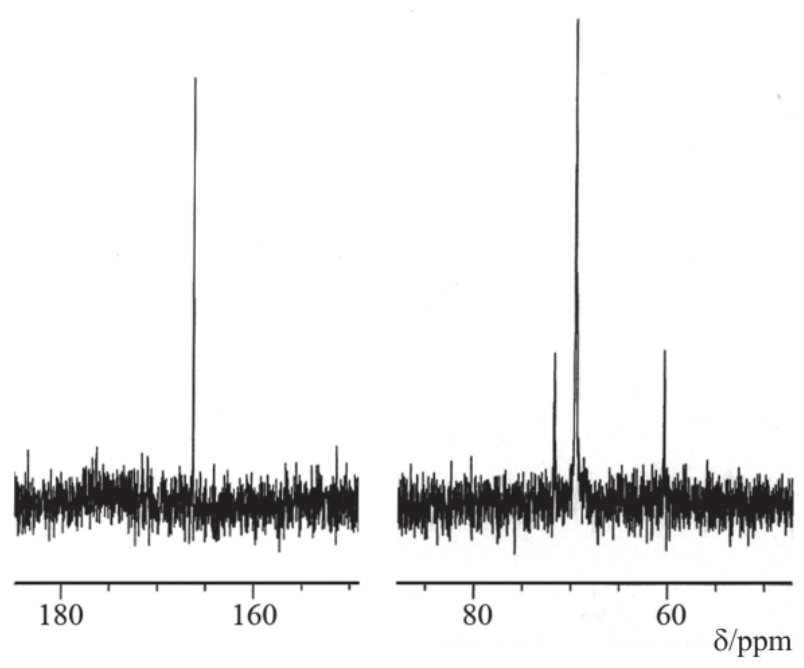

Figure 3. ${ }^{13} \mathrm{C}$ NMR spectrum of a fullerol solution in $\mathrm{D}_{2} \mathrm{O}$, measured at $300 \mathrm{MHz}$ operating at $100 \mathrm{MHz}$ and room temperature (chemical shift $\delta$ in ppm units).

(see, e.g. Johnson et $a l .{ }^{26}$ ), due to the 60 equivalent carbons in the structure. The other three signals, at $\delta=$ 72, 70 and $60 \mathrm{ppm}$, are in the range of ${ }^{13} \mathrm{C}$ NMR chemical shifts for $\mathrm{C}-\mathrm{O}$ in either heteroaromatic alcohols or ethers. ${ }^{19}$ Although the three signals indicate that there are definitively three different $\mathrm{C}$-O bonds in the material, their origin is yet unclear. They can be caused by a mixture of fullerols with different numbers of $\mathrm{OH}$, isomerism and polyhydroxylation of $\mathrm{C}_{70}$ (also present in lower concentrations in the starting sublimated material, see e.g. in the insert of Figure 4), among other possibilities. Further experiments are still required to clarify this point. However the presence of ${ }^{13} \mathrm{C}$ NMR signals due to carbons bond to oxygen is totally consistent with the presence of the infrared lines from $\mathrm{C}-\mathrm{OH}$ and $\mathrm{C}-\mathrm{O}$ vibrations. 


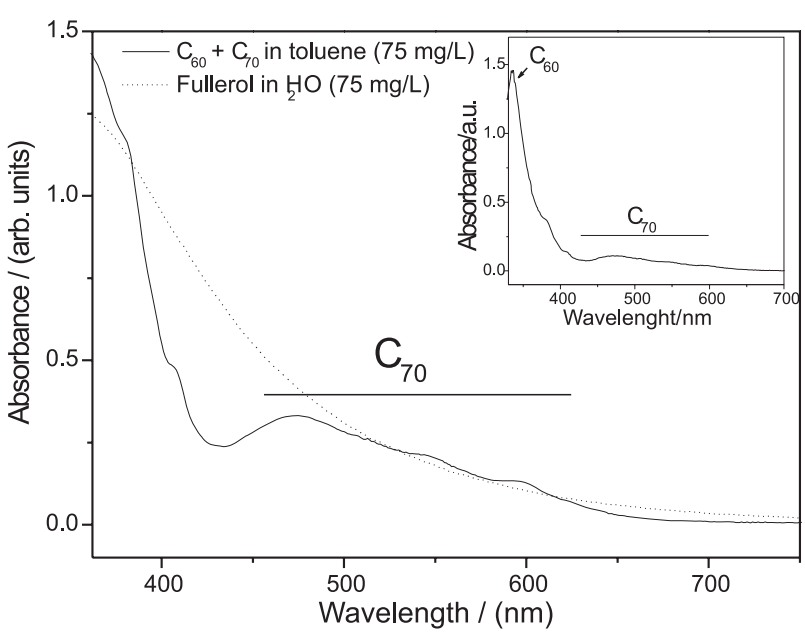

Figure 4. Optical absorption spectra of the starting material (sublimated $\mathrm{C}_{60}+\mathrm{C}_{70}$ ) in toluene and the fullerol sample in water, both with absolute concentrations of $75 \mathrm{mg} \mathrm{L}^{-1}$. The insert shows the spectrum of the fullerene mixture with a lower concentration $\left(15 \mathrm{mg} \mathrm{L}^{-1}\right)$ revealing in more detail the $\mathrm{C}_{60} \mathrm{UV}$ band. Note that the bands due to $\mathrm{C}_{70}$ are much weaker than the main absorption band of the $\mathrm{C}_{60}$ that falls in the UV range.

In order to estimate the number of hydroxyl groups attached to each fullerene cage, TGA analysis was performed, following the method published in Goswami et al. ${ }^{27}$ and assuming that a simple polyhydroxylation occurred leading to a product like $\mathrm{C}_{60}(\mathrm{OH})_{\mathrm{n}}$. The TGA runs and their first derivative showed the separation of the $\mathrm{OH}$ groups from the fullerene cages, starting above $150{ }^{\circ} \mathrm{C}$, in accordance to reference 26 . Between $150{ }^{\circ} \mathrm{C}$ and $570{ }^{\circ} \mathrm{C}$, no fullerene sublimation occurs at atmosphere pressure and measured weight loss by dehydroxylation was $24.3 \%$. Above $570{ }^{\circ} \mathrm{C}$ the weight loss was $54.5 \%$ due to degradation of $\mathrm{C}_{60}$. With these results the number of hydroxyl groups per fullerene molecule (n) could be estimated according to:

$n=\frac{m o l w t\left(C_{60}\right)}{m_{r}\left(C_{60}\right)} \times \frac{m_{r}\left((\mathrm{OH})_{n}\right)}{m o l w t(\mathrm{OH})}=\frac{720}{54.5} \times \frac{24.3}{17} \approx 19 \pm 1$

The values in equation (1) are related to the ratio between the molecular weight of $\mathrm{C}_{60}\left(\mathrm{~mol} \mathrm{wt}\left(\mathrm{C}_{60}\right)\right)$ and its measured relative mass $\left(m_{r}\left(C_{60}\right)\right)$, times the ratio between the measured relative mass of each hydroxyl group $\left(m_{r}(\mathrm{OH})\right)$ and its molecular weight ( $\mathrm{mol} w t(\mathrm{OH})$ ), which gives the average number of hydroxyl groups per fullerene. This average number of 19 hydroxyl groups per fullerene matches several results in the literature that describe functionalizations in the range of 6 to $28 \mathrm{OH}$ groups. ${ }^{21-25}$ The deviation of $\Delta \mathrm{N}= \pm 1$ appears when the presence of $\mathrm{C}_{70}$ in relative concentration ratios of $\left[\mathrm{C}_{70}\right] /$ $\left[\mathrm{C}_{60}\right]$ up to $10 \%$, is taken into account. This upper limit for $\left[\mathrm{C}_{70}\right] /\left[\mathrm{C}_{60}\right]$ ratio was estimated by the optical absorption spectra in toluene solution.
In the Figure 4 the optical absorption spectra of solutions of pristine fullerenes (in toluene) and the fullerol product (in water) are shown $\left(75 \mathrm{mg} \mathrm{L}^{-1}\right)$. The fullerene spectra consist of a strong ultraviolet (UV) band due to $\mathrm{C}_{60}$ and much weaker lines due to $\mathrm{C}_{70}$ in the visible range (see e.g. reference 20). The insert shows these bands in detail for a more diluted solution of $\mathrm{C}_{60}+\mathrm{C}_{70}$ in toluene (15 mg L L $\mathrm{me}^{-1}$. Thellow color of the fullerol solution is due to a broad band, probably centered in the UV, whose tail extends into the visible range.

\section{Conclusions}

A wide variety of techniques was employed to successfully characterize the fullerenes and fullerols $\mathrm{C}_{60}(\mathrm{OH})_{18-20}$ synthesized in high yields $(87 \%)$ by our group in an alkaline aqueous solution under an $\mathrm{O}_{2}$-rich atmosphere. The combination of spectroscopic and gravimetric techniques has shown that these are complementary in the study of functionalized fullerenes, a necessary step in order to achieve an efficient and well controlled method for the production of these structures. For instance, controlling the number of hydroxyl groups attached to each fullerene molecule will allow us to synthesize structures with different water-solubility as well as reactivity against free-radicals, properties which are fundamental for biomedical applications. Purification of fullerenes via sublimation was confirmed as a reliable and practical procedure.

\section{Acknowledgments}

The authors would like to acknowledge the CNPq, FAPEMIG and the Instituto do Milênio em Nanociências for financial support. We are also grateful to Juliana Antunes de Sene, Sérgio de Oliveira e Érick Souza de Ávila for useful discussions and laboratorial support.

\section{References}

1. Kroto, H. W.; Heath, J. R.; O’Brien, S. C.; Curl, R. F.; Smalley, R. E.; Nature 1985, 318, 162.

2. Bosi, S.; Ros, T. D.; Spalluto, G.; Prato, M.; Eur. J. Med. Chem. 2003, 38, 913.

3. Chiang, L. Y.; Lu, F.-J.; Lin, J.-T.; J. Chem. Soc., Chem. Commun. 1995, 1283.

4. Lai, H. S.; Chen, W. J.; Chiang, L. Y.; World J. Surg. 2000, 24, 450.

5. Jeng, U. S.; Lin, T. L.; Chang, T. S.; Lee, H. Y.; Hsu, C. H.; Hsieh, Y. W.; Canteenwala, T.; Chiang, L. Y.; Prog. Colloid Polym. Sci. 2001, 118, 232. 
6. Dugan, L. L.; Gabrielsen, J. K.; Yu, S. P.; Lin, T.-S.; Choi, D. W.; Neurobiol. Dis. 1996, 3, 129.

7. Chiang, L. Y.; Upasani, R. B.; Swirczewski, J. W.; J. Am. Chem. Soc. 1992, 114, 10154.

8. Chiang, L. Y.; Swirczewski, J. W.; Hsu, C. S.; Chowdhury, S. K.; Cameron, S.; Creegan, K. J.; J. Chem. Soc., Chem. Commun. 1992, 1791.

9. Chiang, L. Y.; Upasani, R. B.; Swirczewski, J. W.; Soled, S.; J. Am. Chem. Soc. 1993, 115, 5453.

10. Chen, B.-H.; Huang, J.-P.; Wang, L. Y.; Shiea, J.; Chen, T.-L.; Chiang, L. Y.; J. Chem. Soc. 1998, 1171.

11. Chen, B.-H.; Canteenwala, T.; Patil, S.; Chiang, L. Y.; Synth. Commun. 2001, 31, 1659.

12. Chiang, L. Y.; Bhonsle, J. B.; Wang, L.; Shu, S. F.; Chang, T. M.; Hwu, J. R.; Tetrahedron 1996, 52, 4963.

13. Schneider, N. S.; Darwish, A. D.; Kroto, H. W.; Taylor, R.; Walton, D. R. M.; J. Chem. Soc., Chem. Commun. 1994, 463.

14. Li, J.; Takeuchi, A.; Ozawa, M.; Li, X.; Saigo, K.; Kitazawa, K.; J.Chem. Soc., Chem. Commun. 1993, 1784.

15. Li, T.; Li, X.; Huang, K.; Jiang, H.; Li, J.; J. Cent. South Univ. Technol. (Engl. Ed.) 1999, 6, 35.

16. Gonzalez, K. A.; Wilson, L. J.; Wu, W.; Nancollas, G. H.; Bioorg. Med.Chem. 2002, 10, 1991.

17. Husebo, L. O.; Sitharaman, B.; Furukawa, K.; Kato, T.; Wilson, L. J.; J. Am. Chem. Soc. 2004, 126, 12055.
18. Zhang, J. -M.; Yang, W.; He, P.; Zhu, S. -Z.; Chin. J. Chem. 2004, 22, 1008 .

19. Silverstein, R. M.; Bassler, G. C.; Morrill, T. C.; Spectrometric Identification of Organic Compounds, $5^{\text {th }}$ ed., Wiley \& Sons: Singapore, 1991.

20. Dresselhaus, M. S.; Dresslhaus, G.; Eklund, P. C.; Science of Fullerenes and Carbon Nanotubes, $1^{\text {st }}$ ed., Academic Press: San Diego, 1996.

21. Chiang, L. Y.; Upasani, R. B.; Swirczewski, J. W.; J. Am. Chem. Soc. 1992, 114, 10154.

22. Chiang, L. Y.; Swirczewski, J. W.; Hsu, C. S.; Chowdhury, S. K.; Cameron, S.; Creegan, K.; J. Chem. Soc., Chem. Commun. 1992, 1791.

23. Chiang, L. Y.; Upasani, R. B.; Swirczewski, J. W.; Soled, S.; J. Am. Chem. Soc. 1993, 115, 5453.

24. Chen, B.-H.; Huang, J.-P.; Wang, L. Y.; Shiea, J.; Chen, T.-L.; Chiang, L. Y.; J. Chem. Soc., Perkin Trans. 1 1998, 1171.

25. Chen, B.-H.; Canteenwala, T.; Patil, S.; Chiang, L. Y.; Synth. Commun. 2001, 31, 1659.

26. Johnson, R.D.; Meijer, G.; Salem, J.R.; Bethune, D. S.; J. Am. Chem. Soc. 1991, 113. 3619.

27. Goswami, T. H.; Singh, R.; Alam, S.; Mathur, G. N.; Thermochimica Acta 2004, 419, 97.

Received: January 25, 2006

Published on the web: September 26, 2006 